\author{
Marta JAROSZEWICZ \\ Ośrodek Studiów Wschodnich (OSW) \\ marta.jaroszewicz@osw.waw.pl
}

\title{
MIGRACJE Z UKRAINY DO UNII EUROPEJSKIEJ Z PERSPEKTYWY RYZYKA
}

ABSTRACT Ukrainian migration to the European Union from the risk perspective The aim of this paper is to analyse, through the prism of risk theories, migration from Ukraine to the European Union in a multidimensional perspective. Risks taken by different actors associated with migration along this route have been considered. At the micro-level these are risks borne by Ukrainian migrants themselves. At the macro-level these are risks borne by both states of destination and origin. The concept of risk is the most suitable theoretical approach to be applied in the case of analyzing Eastern European migration. Migration to the fortress "Europe" creates many risks for the migrants and is treated as a challenge by the state actors. At the same time, it cannot be regard as a as a security threat. It is very modest both in the numbers and possible adverse consequences for all stakeholders involved. The article pays special attention to the issue of possible risks related to the eruption of armed conflict in Eastern Europe. It argues that those risks have grown but not significantly and the most affected actor is the Ukrainian state itself, who in a long-term perspective may experience dramatic demographic challenges. Both migrants as well the EU destination states may be at higher risk only in a case of serious destabilization at the whole Ukrainian territory.

Słowa kluczowe: migracje, Ukraina, Unia Europejska, teoria ryzyka Keywords: migration, Ukraine, European Union, risk theory 


\section{WPROWADZENIE}

Po rozpadzie ZSRR migracje zagraniczne stały się jedną z ważniejszych strategii życiowych wybieranych przez obywateli Ukrainy, borykających się z biedą, brakiem perspektyw zawodowych i niestabilnością polityczną. Początkowo Ukraińcy wyjeżdzali głównie do Rosji, jednak z czasem kraje UE stały się miejscem docelowym dla około połowy ogółu ukraińskich migrantów zarobkowych. Bezpośrednio przed rosyjską aneksją Krymu i wybuchem konfliktu zbrojnego we wschodniej Ukrainie wiosną 2014 r. migracje do UE charakteryzowały się stabilną zmiejszającą się dynamiką. Migracje te miały coraz mniej nieuregulowany charakter, zaś migranci byli coraz bardziej świadomi podejmowanego ryzyka i swoich możliwości na rynku pracy. Wybuch konfliktu zbrojnego zasadniczo zmienił dotychczasową sytuację i zwiększył ryzyko wystąpienia niekorzystnych zjawisk związanych z migracją Ukraińców. Wzrosło ryzyko przede wszystkim dla samych migrantów podejmujących decyzje migracyjne w pośpiechu (i coraz częściej decydujących się na nieregularną migrację), lecz także dla państw docelowych nieprzygotowanych na szybki wzrost dynamiki migracji Ukraińców oraz dla samej Ukrainy stojącej przed coraz większymi zagrożeniami demograficznymi.

Celem niniejszego artykułu jest ujęcie najnowszej, „kryzysowej” migracji obywateli Ukrainy do Unii Europejskiej z punktu widzenia teorii ryzyka. Ze względu na rzadkie dotychczas stosowanie teorii ryzyka i perspektywy bezpieczeństwa do badania migracji niniejszy artykuł ma prekursorski charakter. To podejście badawcze, które można zaliczyć do tzw. krytycznych badań nad migracjami, znajduje się obecnie na wczesnym etapie rozwoju. Zapewne jednak ze względu na bezprecedensowy napływ uchodźców z Bliskiego Wschodu do UE, jaki nastąpił w ostatnim czasie, oraz związaną z tym rosnącą polityzację migracji i zastosowanie przez państwa UE całego spektrum instrumentów bezpieczeństwa do zatrzymania tego zjawiska, naukowe podejście do ryzyka $\mathrm{w}$ migracjach znajdzie swoje dalsze rozwinięcie. To nowe ujęcie staje przed szeregiem wyzwań, polegających na braku odpowiedniej literatury teoretycznej i empirycznej. W tej sytuacji wiele hipotez przedstawionych w artykule nie może zostać wykazanych na gruncie istniejących badań.

Teoria ryzyka, różnie definiowana przez poszczególne dziedziny nauki, wydaje się najbardziej odpowiednia do ujęcia tematu najnowszej migracji Ukraińców. Po pierwsze, ryzyko wydaje się uniwersalnym podejściem badawczym obejmującym zarówno perspektywę migrantów, jak i państw. Po drugie, wybuch wojny na wschodzie Ukrainy zwiększa prawdopodobieństwo wystąpienia negatywnych skutków towarzyszących migracji. W sytuacji stałego zagrożenia dla bezpieczeństwa migranci są zmuszeni podejmować mniej racjonalne i bardziej ryzykowne decyzje migracyjne, a państwa wysyłające i przyjmujące mają do czynienia nie tylko z ekonomicznym czy społecznym oddziaływaniem migracji, ale też z trudno przewidywalnym wpływem konfliktu zbrojnego. Po trzecie wreszcie, ryzyko lepiej odzwierciedla dylematy związane z polityką migracyjną w zmieniającym się globalnym świecie niż powszechne, lecz często nieuzasadnione łączenie migracji z problematyką bezpieczeństwa (tzw. „sekurytyzacja” migracji). 
Niniejszy tekst postara się odpowiedzieć na pytanie, czy wybuch konfliktu zbrojnego na wschodniej Ukrainie wpłynął na wzrost niekorzystnych zjawisk związanych z migracją Ukraińców do UE, zwłaszcza na wzrost nieuregulowanej (nieudokumentowanej) migracji ${ }^{1}$, a także czy można dokonać klasyfikacji tych zjawisk i ich znaczenia dla poszczególnych aktorów procesu: migrantów, państw przyjmujących oraz państwa pochodzenia. Procesy migracyjne zostaną przeanalizowane przy wykorzystaniu teorii ryzyka oraz wcześniej współopracowanego przez autorkę modelu analizy ryzyka (na ryzyko będą składać się następujące komponenty: niepowodzenie i jego efekty, prawdopodobieństwo wystąpienia niepowodzenia i jego formy, znaczenie niepowodzenia) ${ }^{2}$.

\section{PRZEGLĄD LITERATURY, TERMINOLOGIA I ZAŁOŻENIA METODOLOGICZNE}

Pojęcie ryzyka jest używane przez różne dyscypliny nauki, poczynając od matematyki, przez ekonomię i naukę o zarządzaniu, aż po psychologię, socjologię i nauki polityczne. Jednocześnie jednak określenie „ryzyko” jest niezwykle rzadko wykorzystywane w badaniach nad migracjami w skali makro, zwłaszcza w podejściu politologicznym. W zasadzie jedyną znaną autorce pracą, która w sposób bardziej kompleksowy podejmuje to zagadnienie, jest praca Arne Niemanna i Natalie Schmidthäussler The Logic of EU Policy Making on (Irregular) Migration: Securitisation or Risk?³. Określenie „ryzyko” zrobiło natomiast zawrotną karierę w polityce migracyjnej realizowanej przez państwa, zwłaszcza w kontekście zwalczania nieuregulowanej migracji. Również w socjologii oraz ekonomii (zwłaszcza w tzw. nowej teorii migracji), badających bądź zachowania indywidualnych migrantów, bądź gospodarstw domowych, ryzyko jest dość dobrze opisaną kategorią.

Gdy jest mowa o „ryzyku”, najczęściej rozumie się przez nie prawdopodobieństwo, że w wyniku jakiegoś działania danego podmiotu wystąpią niepożądane skutki lub konsekwencje dla tego podmiotu. Ortwin Renn definiuje „ryzyko” jako prawdopodobieństwo, że niepożadany stan rzeczywistości (odwrotne efekty) moga wystapić jako rezultat wydarzeńn naturalnych lub dziatań ludzkich ${ }^{4}$. Warto pamiętać, że podmiot podejmujący

1 W artykule autorka chce odejść od terminu „nielegalna migracja” jako jednoznacznie wiążącego ten rodzaj migracji z zagrożeniami natury kryminalnej. W języku angielskim powszechnie używa się terminu irregular migration. W języku polskim występuje kilka określeń: „migracja nieudokumentowana”, „migracja bez zezwolenia”. Autorka zdecydowała się na używanie określenia „nieuregulowana migracja" jako terminu najbardziej pojemnego, obejmującego różne przypadki migracji niekoncesjonowane przez państwo.

2 Zob.: M. Jaroszewicz, M. Kindler, Irregular Migration from Ukraine and Belarus to the EU. A Risk Analysis Study, Warsaw 2015, CMR Working Papers, nr 80 (138).

3 A. Niemann, N. Schmidthäussler, The Logic of EU Policy Making on (Irregular) Migration: Securitisation or Risk?, Paper given at the UACES conference: „Exchanging Ideas on Europe 2012: Old Borders - New Frontiers", 3-5 IX 2012, Passau, Germany.

4 O. Renn, Concepts of Risks: A Classification, [w:] Social Theories of Risk, red. S. Krimsky, D. Golding, Westport 1992, s. 53-79. 
ryzyko może i zwykle analizuje je w kontekście przyczynowo-skutkowym. Nie jest jednak możliwa ocena ryzyka w oparciu o obiektywna analizę, prawie zawsze w grę wchodzą elementy intuicyjne, emocjonalne, kontekst społeczny5. Właśnie na tę cechę ryzyka, jego dyskursywny charakter, kładzie nacisk podejście socjologiczne w analizie ryzyka.

Warto także pamiętać o różnicy między ryzykiem a niepewnością. Ryzyko nie oznacza zupełnego braku kontroli nad skutkami swoich decyzji, przeciwnie - ryzyko może być minimalizowane, można nim zarządzać. Zwraca na to uwagę przede wszystkim podejście ekonomiczne. Według Odeda Starka, przedstawiciela tzw. teorii kapitału ludzkiego, ryzyko związane z migracją jest brane pod uwagę przez migrantów, którzy choć nie są w stanie dokładnie go przeliczyć, to uwzględniają je w swoich przyszłych dochodach $^{6}$. Przedstawiciele tzw. nowej ekonomii migracji uważają, że to gospodarstwa domowe, a nie indywidualni migranci, zarządzają ryzykiem podejmowanym przez migrujących członków rodziny, zaś migracja nie jest niczym innym niż strategią dywersyfikacji dochodów minimalizującą ryzyka związane z ewentualną utratą dochodów w kraju pochodzenia?

Ze swojej natury politologia rzadko zajmuje się poziomem poszczególnych jednostek ludzkich i w zasadzie praktycznie nie zajmuje się badaniem ryzyka w migracjach. Jeden w nielicznych wyjątków stanowi stworzona przez Michela Foucaulta teoria „rządomyślności” (govermentality) mająca objaśniać techniki i strategie, przez które spoteczeństwo daje sobą kierować. Wskazuje ona na ryzyko jaką istotną kategorię stosowaną przez władze państwowe, by kierować społeczeństwem, głównie dzięki wpływowi wywieranemu na debatę publiczną, media i organizacje pozarządowe. Rządy mają bowiem tendencję, by definiować określone grupy społeczne jako „grupy ryzyka”. Powszechne umieszczanie w tej kategorii migrantów z jednej strony oznacza odgórne wiązanie tej grupy społecznej z zagrożeniami dla bezpieczeństwa, z drugiej zaś ustawia migrantów w pozycji osób znajdujących w grupie ryzyka bez ich woli, niebędących w stanie podejmować świadomych decyzji dotyczących migracji i ich konsekwencji ${ }^{8}$.

Nieco odmiennie niż politologia kwestie ryzyka i migracji postrzegają nauka o bezpieczeństwie oraz stosunki międzynarodowe. W tej perspektywie, dość powszechnie wiążącej migrację, zwłaszcza nieuregulowaną, z zagrożeniami dla bezpieczeństwa państwa oraz bezpieczeństwa międzynarodowego, perspektywa ryzyka ma doprowadzić do wyparcia paradygmatu „sekurytyzacyjnego” migracji. Zdaniem Niemanna i Schmidthaussler perspektywa ryzyka jest bardziej odpowiednia do analizowania związków pomiędzy migracją i bezpieczeństwem, albowiem migracje nie są czymś wyjątkowym, z czym należy walczyć, lecz stają się powszechną normą codziennego życia9. Tymcza-

J.O. Zinn, P. Taylor-Gooby, The Current Significance of Risk, [w:] Risk in Social Science, red. ciż, Oxford 2006.

6 O. Stark, The Migration of Labour, Cambridge-Oxford 1991.

7 D.S. Massey i in., Theories of International Migration: A Review and Appraisal, „Population and Development Review" 1993, Vol. 19, nr 3, s. 431-466, [online] http://dx.doi.org/10.2307/2938462.

8 M. Valverde, Police, Sovereignty and Law: Faoucaultian Reflections, [w:] Police and the liberal state, red. M.D. Dubber, M. Valverde, Standford 2008, s. 15-32, Critical Perspectives on Crime and Law.

9 A. Niemann, N. Schmidthäussler, The Logic of EU Policy Making... 
sem wypracowana w latach 80. ubiegłego wieku przez tzw. szkolę kopenhaską stosunków międzynarodowych koncepcja „sekurytyzacji” migracji opisuje tworzenie się wokół migracji atmosfery zagrożenia i wyjątkowości, co prowadzi do definiowania tego zjawiska w kategorii bezpieczeństwa ${ }^{10}$.

Perspektywa politologiczna nie dostarcza niestety pogłębionej wiedzy o metodologicznych możliwościach wszechstronnego badania ryzyka w migracjach. Jeśli chodzi o systemowe metody analizy ryzyka w skali makro, to największy dorobek w tym zakresie mają matematyka oraz nauka o zarządzaniu, na których to także oparto praktyczne metody analizy ryzyka stosowane przez instytucje porządku publicznego. Podejście systemowe (najczęściej ilościowe) zwykle szacuje ryzyko poprzez: 1) prawdopodobieństwo wystąpienia niepowodzenia; 2) oszacowanie strat; 3) stworzenie modelu analizy ryzyka łączącego w sobie zmienność i niepewność prawdopodobieństwa wystąpienia porażki i jej konsekwencji ${ }^{11}$. Jednak trudno zastosować jakościowe modele analizy ryzyka do zjawisk społecznych, takich jak migracja, z bardzo ograniczoną ilością wiarygodnych danych. Ponadto, ryzyko w migracjach nie jest kategorią obiektywną, jest ściśle powiązane z kontekstem społecznym i w zależności od okoliczności może być postrzegane jako istotne lub też nie. Różna może być także percepcja i znaczenie jego konsekwencji. Kluczową różnicą metodologiczną w podejściu do ryzyka pomiędzy naukami ścisłymi a humanistycznymi jest przede wszystkim odmienne postrzeganie tego, czy ryzyko jest kategorią obiektywną, możliwą do ilościowego zmierzenia, czy też jest konstruktem socjologicznym zależnym od percepcji.

Dlatego też na potrzeby tego artykułu autorka proponuje następującą definicję ryzyka i jego wymiarów. Ryzyko będę rozumieć jako prawdopodobieństwo wystąpienia negatywnych konsekwencji działań podejmowanych przez dany podmiot (jednostkę lub państwo), przy czym ocena możliwości wystąpienia ryzyka rzadko kiedy ma charakter obiektywny, a jest głównie konstruktem społecznym. Ryzyko składa się z następujących wymiarów:

1) niepowodzenie - co niepowodzenie oznacza dla poszczególnej kategorii aktorów, jakie są główne typy niepowodzenia w migracjach charakterystyczne dla migrantów, krajów przyjmujących i wysyłających i jak są one postrzegane, jakie środki zaradcze są podejmowane, by uniknąć ryzyka;

2) prawdopodobieństwo wystąpienia niepowodzenia i jego formy - jakie jest prawdopodobieństwo wystąpienia niepowiedzenia dla poszczególnej kategorii omawianych aktorów i jakie są formy niepowodzenia;

3) skutki i znaczenie niepowodzenia - jak ważne jest niepowodzenie dla funkcjonowania każdego z omawianych aktorów, jakie są skutki tego niepowodzenia. Ryzyko rozumiane jako funkcja tych komponentów będzie badane oddzielnie dla trzech kategorii podmiotów: samych migrantów (poziom mikro) oraz państwa wysy-

$10 \mathrm{~J}$. Huysmans, The Politics of Insecurity. Fear, Migration and Asylum in the EU, London-New York 2006, New International Relations.

11 N.S. Arunraj, S. Mandal, J. Maiti, Modeling Uncertainty in Risk Assessment: An Integrated Approach with Fuzzy Set Theory and Monte Carlo Simulation, "Accident Analysis and Prevention” 2013, Vol. 55, nr 3, s. 242-255, [online] http://dx.doi.org/10.1016/j.aap.2013.03.007. 
łającego i państw przyjmujących (poziom makro). Warto pamiętać, że odmienne kwestie będą kluczowe w postrzeganiu i doświadczaniu ryzyka przez tych aktorów. Dla migrantów, jednostek bezpośrednio zaangażowanych w proces migracji i osobiście ponoszących negatywne konsekwencje decyzji migracyjnych, ryzyko związane z migracją jest najbardziej namacalne i dotyczy zarówno kwestii ekonomicznych (w tym pokrycia kosztów podroży i kosztów utrzymania w kraju docelowym), kwestii społecznych i kulturowych (komfort życia, dostęp do opieki zdrowotnej i instytucji publicznych, stosunek społeczeństwa przyjmującego), jak i fundamentalnych kwestii bezpieczeństwa (zagrożenia dla zdrowia, a nawet ryzyko śmierci).

Jeśli chodzi o państwa, to z racji potęgi aparatu państwowego i istniejących możliwości kontroli, ryzyka związane z migracją nie mają raczej charakteru bezpośredniego zagrożenia. Mówimy w tym przypadku bardziej o pośrednich negatywnych konsekwencjach politycznych migracji (brak akceptacji imigrantów przez społeczeństwo i elity) i społecznych (słaba integracja migrantów w kraju docelowym) oraz ekonomicznych (istnienie szarej strefy zatrudnienia, bezrobocie wśród migrantów). Jeśli chodzi o potencjalne związki migracji i międzynarodowego terroryzmu, to trudno oddzielić dwa zjawiska: niechęć do migrantów i powszechne postrzeganie ich w kategorii zagrożenia związane ze swojego rodzaju kolektywną psychologiczną traumą po okrutnych zamachach terrorystycznych w USA i UE oraz rzeczywiste wykorzystywane przez siatki terrorystyczne kanałów migracyjnych do przerzutu terrorystów ${ }^{12}$.

Jeśli chodzi o państwo wysyłające, to największe ryzyko wiąże się z utratą części populacji i związanymi z tym zagrożeniami demograficznymi. Kolejną kwestią jest także istnienie diaspory za granicą i sformułowanie właściwej strategii komunikacji z nią.

Artykuł został oparty na badaniach ilościowych (dostępnych danych statystycznych na temat migracji z Ukriany do UE), analizie dostępnej literatury i materiałów źródłowych, jak też na badaniach jakościowych, jakie autorka przeprowadziła podczas wywiadów eksperckich w Polsce i na Ukrainie w okresie od kwietnia 2014 do stycznia 2015 r.

Przedmiotem niniejszego artykułu jest migracja obywateli Ukrainy do Unii Europejskiej, przez którą autorka rozumie także migrację nieuregulowaną, najczęściej odbywającą się w postaci legalnego wjazdu i nielegalnego pobytu bądź też legalnego wjazdu i legalnego pobytu, lecz pracy bez zezwolenia. Cezurą czasową jest rok 2014, a zatem okres, kiedy nastąpiła aneksja Krymu przez Rosję i wybuch konfliktu zbrojnego we wschodniej Ukrainie. Głównym celem niniejszego artykułu będzie zatem odpowiedź na pytanie, czy po wybuchu konfliktu zbrojnego wiosną 2014 r. oraz w obliczu dramatycznego kryzysu gospodarczego wzrosły różnego rodzaju ryzyka związane z migracją obywateli Ukrainy do UE.

Analiza skali mezzo omawianego zjawiska, a zatem zbadanie charakteru ryzyka w migracjach widzianego z perspektywy nieformalnych sieci migracyjnych, jak też organizacji zajmujących się pomocą migrantom, pozwoliłaby na bardziej kompleksowe uchwycenie „drogi” migranta, a także ujecie ryzyka w migracjach w bardziej syste-

12 T. Faist, „Extention do domaine de la lutte”: International Migration and Security before and after September 11, „International Migration Review” 2002, Vol. 31, nr 1, s. 7-14, [online] http://dx.doi.org/ 10.1111/j.1747-7379.2002.tb00065.x. 
mowy sposób. Niestety badania empiryczne prowadzone przez autorkę nie objęły tej perspektywy. Jest to niewątpliwie wyzwanie, które powinno być podjęte w kolejnych badaniach.

\section{UKRAIŃSKA MIGRACJA DO UE}

Ukraińska migracja do UE odbywa się w bezprecedensowo niekorzystnej dla niej sytuacji politycznej i humanitarnej w Europie. Unia Europejska stoi przed wyzwaniem największej od czasów II wojny światowej fali uchodźczej i migracyjnej wywołanej wojną domową w Syrii oraz pogarszaniem się sytuacji bezpieczeństwa w innych krajach Bliskiego Wschodu i Afryki Północnej. Zgodnie ze statystyką Eurostatu w 2015 r. UE przyjęła ponad 1,2 mln wniosków od osób poszukujących ochrony międzynarodowej, choć w sytuacji tak ogromnej dynamiki systemy rejestracji osób poszukujących ochrony międzynarodowej oraz migrantów okazały się zawodne. Niespotykana presja migracyjna, nieefektywność systemu kontroli i rejestracji migracji w najbardziej popularnych wśród uchodźców państwach UE, nieadekwatność dotychczasowego ustawodawstwa azylowego na poziomie unijnym, a wreszcie brak wspólnej wizji wewnątrz państw UE, jak należy reagować na kryzys migracyjny, spowodowały, że inne wyzwania związane z migracją do UE, w tym migracja ekonomiczna i możliwości jej efektywnego zagospodarowania, odeszły na dalszy plan. Kolejnym czynnikiem politycznie niesprzyjającym migracji obywateli Ukrainy stały się rosnące nastroje antyimigranckie w krajach Unii Europejskiej ${ }^{13}$.

Tymczasem jak wskazują dane Eurostatu za 2014 r., po raz drugi z rzędu obywatele Ukrainy zajmują pierwsze miejsce, jeśli chodzi o liczbę wydawanych po raz pierwszy zezwoleń na pobyt w krajach Unii Europejskiej. W 2014 r. obywatele Ukrainy otrzymali aż 302 tys. nowych zezwoleń na pobyt w krajach UE (13\% wszystkich wydanych zezwoleń), wyprzedzając obywateli Stanów Zjednoczonych (199 tys.) oraz Chin (169 tys.) i Indii (134 tys.). Najwięcej zezwoleń obywatele Ukrainy otrzymali w Polsce (247 tys., czyli 80\% wszystkich zezwoleń wydanych Ukraińcom $)^{14}$. Ogółem według danych Eurostatu pod koniec 2014 r. obywatele Ukrainy posiadali w krajach UE-28 861 tys. zezwoleń na pobyt (różnego typu, lecz uprawniających do pobytu na okres powyżej trzech miesięcy ${ }^{15}$. Najwięcej zezwoleń wydały Polska, Włochy i Czechy. Warto jednocześnie zauważyć, że w świetle tych oficjalnych statystyk liczba obywateli Ukrainy posiadających zezwolenie na pobyt w UE wzrosła w niewielkim stopniu - pod koniec grudnia 2013 r. obywatele Ukrainy posiadali w UE-28 849 tys. zezwoleń na pobyt (szerzej zob. tab. 1).

13 Szerzej zob.: N. Banulescu-Bogdan, S. Fratzke, Europe's Migration Crisis in Context: Why Now and What Next?, „Migration Policy Source” 2015, 24 IX, [online] http://www.migrationpolicy.org/artic le/europe-migration-crisis-context-why-now-and-what-next, 25 IV 2016.

14 Eurostat News Release, 185/2015, 20 X 2015, [online] http://ec.europa.eu/eurostat/documents/ 2995521/7038745/3-20102015-BP-EN.pdf/70063124-c3f2-4dfa-96d5-aa5044b927a6, 27 IV 2016.

15 Dane te należy traktować jak orientacyjnie. Jak podaje Eurostat, definicje przyjmowane przez poszczególne kraje członkowskie znacząco się różnią. 
Tabela 1. Wszystkie ważne zezwolenia na pobyt wydane obywatelom Ukrainy w krajach UE-28 (stan na koniec grudnia danego roku)

\begin{tabular}{|r|c|c|c|c|c|c|c|}
\hline UE-2008 & 2008 & 2009 & 2010 & 2011 & 2012 & 2013 & 2014 \\
\hline & 666077 & 729552 & 696239 & 756289 & 782712 & 849946 & 861599 \\
\hline
\end{tabular}

Źródło: Eurostat

Jeśli chodzi o źródła ukraińskie dotyczące szacunków wielkości ukraińskiej diaspory w UE, to brakuje w tym zakresie wiarygodnych danych statystycznych. Wysoką jakością charakteryzują się natomiast regularnie powtarzane badania gospodarstw domowych na temat migracji zarobkowych. Jednak ostatnie tego typu badanie było przeprowadzone przed wybuchem konfliktu na wschodniej Ukrainie i rosyjską agresją. Według danych ogólnoukraińskiego badania migracji zarobkowej w latach 2005-2008 pracowało za granicą 1,5 mln Ukraińców, podczas gdy w latach 2010-2012 już 1,2 $\mathrm{mln}^{16}$. Spadek ten był związany przede wszystkim ze światowym kryzysem gospodarczym i zmniejszeniem się podaży na pracę ukraińskich pracowników w UE i w Rosji. Zmieniły się też strategie migracyjne Ukraińców - zaczęli oni coraz częściej preferować migrację czasową i cyrkulacyjną, która co prawda zmniejszała wysokość zarobków, lecz pozwalała na utrzymanie bliskich więzi z krajem ojczystym. Trend ten był też związany ze zmianą najbardziej popularnych krajów docelowych migracji. O ile w latach 20052008 były to Rosja, Włochy i Czechy, o tyle w latach 2010-2012 dwa pierwsze miejsca zajęły Rosja i Polska. Oba te kraje prowadziły wobec Ukraińców dość liberalną politykę migracyjną, co pozwalało na częste podróże migrantów ${ }^{17}$. W sumie na Rosję i kraje UE przypadało po około $50 \%$ całości przepływów migracyjnych z Ukrainy, przy czym udział Rosji powoli spadał.

Ponadto, jak wskazuje badanie przeprowadzone w latach 2013-2014 przez OSW we współpracy z ośrodkami badawczymi z siedmiu krajów regionu, „przedwojenna” migracja (do czasu aneksji Krymu przez Rosję i wybuchu konfliktu na wschodzie Ukrainy) charakteryzowała się większą racjonalnością wyborów migracyjnych, wynikającą $\mathrm{z}$ bogatego doświadczenia migracyjnego i rozbudowanych sieci migracyjnych w krajach docelowych. Główną cechą tego zjawiska było dążenie migrantów do legalizacji pobytu w krajach pochodzenia, a także coraz popularniejsza migracja edukacyjna. Badanie to starało się także uchwycić rolę migracji nieuregulowanej w przepływach migracyjnych z Ukrainy w krajach wyszehradzkich. Wskazało ono, że spośród zasobu migracyjnego Ukraińców w krajach UE szacowanego na około milion osób od 20 do 40\% przebywa bądź pracuje nielegalnie. Najbardziej rozpowszechnioną formą nieregularności okazał się schemat: legalny pobyt - nielegalna praca $^{18}$.

16 Szerzej zob.: O. Betliy, The Perspective of Ukraine, [w:] Forecasting Migration between the EU, V4 and Eastern Europe. Impact of Visa Abolition, red. M. Jaroszewicz, M. Lesińska, Warsaw 2014, s. 160-162, Raport OSW.

17 M. Jaroszewicz, Polska bardziej atrakcyjna dla ukraińskich imigrantów zarobkowych, „Analizy OSW” 2013, 12 VI.

18 Forecasting Migration between the EU, V4 and Eastern Europe. Impact of Visa Abolition, red. M. Jaroszewicz, M. Lesińska, Warsaw 2014, Raport OSW. 
Przedłużający się konflikt zbrojny na wschodzie Ukrainy, w którego rezultacie zginęło około 6 tys. Osób, a około 2 mln osób musiało opuścić swoje domy, miał wpływ na zauważalny wzrost liczby wniosków o status uchodźcy składanych w krajach UE przez obywateli Ukrainy (szerzej zob. tab. 2). W 2014 r. Ukraińcy złożyli 14 tys. wniosków o status uchodźcy (w 2013 r. - 1120). Wzrost ten należy jednak rozpatrywać w kontekście ogólnounijnym, dla porównania w 2014 r. uciekinierzy z Syrii złożyli w UE 138 tys. wniosków o status uchodźcy, a obywatele Bałkanów Zachodnich 109 tys.

Tabela 2. Liczba wniosków o status uchodźcy złożonych przez obywateli Ukrainy w UE-28 oraz w głównych krajach docelowych (styczeń 2014 - czerwiec 2015)

\begin{tabular}{|c|c|c|c|c|c|c|c|c|}
\hline 2014 I & $\begin{array}{c}2014 \\
\text { IV }\end{array}$ & $\begin{array}{c}2014 \\
\text { IV }\end{array}$ & $2014 X$ & $\begin{array}{c}2014 \\
\text { XII }\end{array}$ & $\begin{array}{c}2015 \\
\text { III }\end{array}$ & $\begin{array}{c}2015 \\
\text { IV }\end{array}$ & $2015 \mathrm{~V}$ & $\begin{array}{c}2015 \\
\text { VI }\end{array}$ \\
\hline UE-28 & 680 & 1020 & 2235 & 1495 & 1850 & 1965 & 1560 & 1685 \\
\hline Czechy & 45 & 35 & 65 & 45 & 90 & 80 & 45 & - \\
\hline Niemcy & 65 & 110 & 575 & 435 & 395 & 460 & 505 & 635 \\
\hline Hiszpania & 25 & 40 & 185 & 105 & 35 & 25 & 70 & - \\
\hline Francja & 50 & 115 & 260 & 145 & 160 & 185 & 125 & 130 \\
\hline Włochy & 70 & 135 & 400 & 230 & 445 & 540 & 360 & 350 \\
\hline Polska & - & 135 & 235 & 195 & 245 & 205 & 155 & 220 \\
\hline Szwecja & 70 & 110 & 175 & 140 & 165 & 135 & 115 & 160 \\
\hline
\end{tabular}

Źródło: Eurostat

Jedynym krajem UE, w którym w latach 2014-2015 nastąpił istotny wzrost migracji z Ukrainy, jest na razie Polska. Wynika to przede wszystkim z poprawiającej się kondycji polskiej gospodarki, uproszczeń $\mathrm{w}$ dostępie do rynku pracy przyznanym obywatelom krajów Partnerstwa Wschodniego oraz istniejącej dużej niszy na rynku pracy w rolnictwie i sektorze indywidualnych gospodarstw domowych. Szczególną rolę w przyciąganiu Ukraińców odgrywa tzw. system oświadczeń. Zgodnie z rozporządzeniem Ministra Pracy z 2011 r. obywatel Ukrainy chcący pracować czasowo w Polsce jest zwolniony z konieczności uzyskiwania zezwolenia na pracę. Wystarczy, że będzie posiadał oświadczenie o zamiarze powierzenia pracy zarejestrowane przez jego przyszłego pracodawcę w powiatowym urzędzie pracy. Procedura ta jest bezpłatna i wymaga minimum formalności. Inne czynniki przyciągające to bliskość językowa i kulturowa, a także niskie koszty podróży. Szczególnie rozpowszechniona jest bezpośrednia komunikacja autobusowa łącząca polskie miasta z często małymi ukraińskimi miejscowościami, obsługująca głównie migrantów. Wraz ze wzrostem liczby Ukraińców w Polsce tworzą się coraz bardziej rozbudowane sieci migracyjne, dzięki czemu migranci czują się coraz bardziej bezpiecznie, mając w swoim języku dostęp do pomocy prawnej, medycznej czy pomocy w zatrudnieniu.

W kontekście polskim bardzo ważne jest rozróżnienie na migrację długoterminową i czasową. Ta pierwsza, choć również wykazuje tendencję wzrostową, to jednak 
w miarę niewielką w liczbach bezwzględnych i jednocześnie jest dość dobrze zobrazowana liczbowo. Ta druga, czasowa, najprawdopodobniej rośnie o wiele bardziej gwałtownie, jednak jak na razie trudno ją uchwycić statystycznie. Jeśli chodzi o migrację długoterminową, to polski spis powszechny z 2011 r. wykazał zaledwie 24 tys. osób deklarujących posiadanie ukraińskiego obywatelstwa. Według danych Urzędu ds. Cudzoziemców pod koniec 2013 r. Ukraińcy posiadali ponad 37 tys. ważnych kart pobytu. Tymczasem we wrześniu 2015 r. takich kart było 62 tys., w tym 26 tys. kart na pobyt stały i 33 tys. zezwoleń na pobyt czasowy ${ }^{19}$. Nie ma niestety informacji, ile kart pobytu wydano osobom pochodzącym z obwodu donieckiego i ługańskiego.

Problemem jest przede wszystkim ocena obecnej liczby ukraińskich migrantów pracujących w Polsce czasowo. W tym przypadku bowiem obywatele Ukrainy bądź otrzymują oświadczenia zezwalające na pracę w trybie uproszczonym do sześciu miesięcy w ciągu roku (jednak tu dane statystyczne nie pokazują liczby osób, lecz liczbę zezwoleń, a jedna osoba może mieć więcej niż jedno zezwolenie), bądź pracują nielegalnie na wizach turystycznych. Można oceniać, że obecnie w Polsce takich osób jest około 300-500 tys. W 2014 r. Ukraińcom wydano 372 tys. oświadczeń o zamiarze powierzenia pracy cudzoziemcowi (60-procentowy wzrost w porównaniu z 2013 r.). Tymczasem tylko w pierwszym półroczu 2015 r. takich oświadczeń od obywateli Ukrainy zarejestrowano aż 402 tys., najwięcej do pracy w rolnictwie. Ponadto, co stanowi polską specyfikę, aż 139 tys. oświadczeń wydano kobietom. Również w tym przypadku nie wiadomo, czy oświadczenia nadal są wydawane głównie mieszańcom Ukrainy Zachodniej, czy też dołączyły do nich osoby z innych części Ukrainy, w szczególności ze wschodu.

Tabela 3. Liczba oświadczeń o zamiarze zatrudnienia cudzoziemca (obywatela Ukrainy) zarejestrowanych przez urzędy pracy w Polsce w pierwszej połowie $2015 \mathrm{r}$.

\begin{tabular}{|c|c|c|c|c|c|c|}
\hline Ogółem & Styczeń & Luty & Marzec & Kwiecień & Maj & Czerwiec \\
\hline 402674 & 49620 & 75316 & 81895 & 64429 & 62994 & 68420 \\
\hline
\end{tabular}

Źródło: Ministerstwo Pracy i Polityki Społecznej RP

\section{PERSPEKTYWA MIGRANTÓW}

Aby zbadać, na jakie ryzyka podczas podróży i następnie podczas pobytu w kraju docelowym narażeni są ukraińscy migranci oraz jakie te ryzyka mają dla nich znaczenie i konsekwencje, należy przede wszystkim odpowiedzieć na pytanie, jaki jest cel migracji tej grupy migrantów. Zwykle jest to bezpieczne dotarcie do planowanego kraju przeznaczenia oraz znalezienie w tym kraju pracy, by móc się utrzymać i przesyłać środki finansowe rodzinie pozostałej w kraju pochodzenia. Aczkolwiek często ten cel nie jest osiągany.

Migrant/migrantka może napotkać wiele niekorzystnych okoliczności, które postrzega jako porażkę i które uniemożliwiają osiągniecie ostatecznego celu. To, czy poniesione porażki będą oznaczały koniec realizacji planów migracyjnych, czy jedy-

19 Dane Urzędu ds. Cudzoziemców RP. 
nie zmuszą migranta/migrantkę do ich adaptacji, zależy od wielu czynników. Przede wszystkim migranci i ich rodziny, planując migrację, dokonują oceny ryzyka, jednak nie jest to w pełni racjonalna ocena, albowiem ograniczona przez niepełność posiadanych informacji, emocje, brak doświadczenia ${ }^{20}$. Przy wyborze kraju docelowego migranci biorą pod uwagę bezpieczeństwo podróży i możliwe potencjalne dochody, jakie mogą osiągnąć w kraju docelowym. Im wyższe potencjalne dochody, tym bardziej migranci są gotowi do poniesienia ryzyka związanego z podróżą. Teoria ta została potwierdzona we wspomnianych badaniach prognostycznych migracji z Europy Wschodniej do Unii Europejskiej i Grupy Wyszehradzkiej przeprowadzonych przez OSW we współpracy z siedmioma instytucjami badawczymi z krajów regionu. Jak pokazały ankiety eksperckie przeprowadzone zarówno na Ukrainie, jak i w krajach docelowych migracji, ukraińscy migranci decydują się na wyjazd do prowadzących mniej otwartą politykę wizową krajów „starej” UE ze względu na możliwości uzyskania wyższego dochodu, zaś do państw Grupy Wyszehradzkiej głównie ze względu na mniejsze ryzyka podróży i możliwości legalizacji pobytu ${ }^{21}$.

Jednak w niektórych przypadkach to, jakie ryzyko migranci są gotowi ponieść, zależy przede wszystkim od ich sytuacji w kraju pochodzenia. Według wspomnianej już nowej teorii migracji zarobkowej ludzie są gotowi zaryzykować migrację, nawet jeśli nie mają perspektyw na osiągniecie godnych dochodów, co wynika ze znacznie większych ryzyk w kraju docelowym wynikających ze specyfiki sektora rolnictwa, w którym są zwykle zatrudnieni ${ }^{22}$. Teoria ta częściowo znajduje potwierdzenie w przypadku migrantów z Ukrainy w UE, zwykle pochodzących z terenów zachodniej Ukrainy, z charakterystycznych dla obszaru posowieckiego tzw. obszarów wiejsko-miejskich. Zapewne także ofiary konfliktów zbrojnych i inni migranci przymusowi są gotowi na podjęcie większego ryzyka migracyjnego. Dość niejednoznaczny jest jednak w tym kontekście przypadek uciekinierów zmuszonych do opuszczenia Krymu oraz wschodniej Ukrainy po rosyjskiej agresji. Według stanu na połowę września 2015 r. oficjalnie zarejestrowana liczba osób wewnętrznie przesiedlonych z obwodu donieckiego i ługańskiego oraz Krymu wynosiła 1,438 mln. Jednak jak dotąd brakuje danych, by potwierdzić, że w tej grupie wzrosła popularność migracji oraz by grupa ta była gotowa do podejmowania bardziej ryzykownych decyzji migracyjnych. Zapewne wynika to z faktu, że znajdują oni schronienie w miejscach tymczasowego przesiedlenia na Ukrainie, a jeśli decydują się na emigrację, to wybierają głównie Rosję, ze względu na znajomość języka i istniejące sieci migracyjne $e^{23}$.

20 M. Kindler, A Risky Business? Ukrainian Migrant Women in Warsaw's Domestic Work Sector, Amsterdam 2011, s. 22, IMISCOE Dissertations.

21 D. Drbohlav, M. Jaroszewicz, The Probable Future Development in International Migration from Ukraine, Belarus and Moldova to Visegrad Countires and the EU, [w:] Forecasting Migration between the EU..., s. 20-54.

22 O. Stark, D.E. Bloom, The New Economics of Labour Migration, „American Economic Review” 1985, Vol. 74, nr 2, s. 173-178.

23 M. Jaroszewicz, Kryzysowa migracja Ukraińców, „Komentarze OSW” 2015, 19 X; F. Düvell, I. Lapschyna, The EuroMaidan Protests, Corruption, and War in Ukraine: Migration Trends and Ambitions, 
Po zastanowieniu się, jak migranci postrzegają ryzyko i planują migrację, warto przeanalizować, jakie porażki mogą ich spotkać. Z racji stosunkowo otwartych kanałów dostępu do terytorium UE, w tym głównie ze względu na liberalną politykę wizową państw strefy Schengen, obywatele Ukrainy mają dość szerokie możliwości legalnej podróży do państw UE. Trudniejszą kwestią jest uzyskanie prawa pobytu w UE, choć jak pokazują wcześniej omówione statystyki, taka możliwość istnieje i stała się o wiele prostsza wraz z wprowadzeniem przez Polskę w 2007 r. procedury dotyczącej krótkoterminowej pracy bez zezwolenia. Literatura przedmiotu dość jednoznacznie wskazuje, że główną formą porażki migranta i zarazem głównym modelem nieuregulowanej migracji jest praca bez zezwolenia przy posiadaniu prawa pobytu w danym kraju UE ${ }^{24}$. Choć prawdopodobieństwo, że migrant/migrantka zostanie przyłapany/a na fakcie pracy bez zezwolenia, jest dość niskie ${ }^{25}$, to jednak grożą wówczas dość surowe konsekwencje, łącznie z wydaleniem z terytorium UE i dalszym zakazem wjazdu. Kolejną potencjalną porażką, na jaką narażeni są ukraińscy migranci, jest bezowocna próba znalezienia zatrudnienia w kraju docelowym, co jest szczególnie dotkliwe zwłaszcza w okresie recesji gospodarczej. Takie sytuacje były dość powszechne wśród ukraińskich migrantów we Włoszech, Hiszpanii i w Czechach podczas kryzysu gospodarczego 2008-2009. Jeśli chodzi o znacznie tej porażki dla konkretnego migranta i jego rodziny, to zależy ono w duże mierze od tego, na ile dane gospodarstwo domowe jest zależne od środków przesyłanych przez migranta (tzw. remittances). Badania pokazują, że w przypadku ukraińskiej migracji do UE ta zależność jest bardzo wysoka ${ }^{26}$. Warto także zwrócić uwagę na inne konsekwencje migracji obywateli Ukrainy do UE, nawet jeśli zrealizowali oni swój główny cel migracyjny. Migranci, zwłaszcza ci nieuregulowani, mają ograniczone możliwości integracji ze społeczeństwem przyjmującym. Poza tym społeczna nietolerancja oraz ksenofobia mogą zasadniczo ograniczyć ich możliwości funkcjonowania w przestrzeni społecznej.

\section{PERSPEKTYWA KRAJÓW PRZYJMUJĄCYCH}

Po tragicznych atakach w Paryżu w listopadzie 2015 r. oraz w obliczu kryzysu migracyjnego w Europie rządy, media oraz społeczeństwa ze zwiększoną siłą powróciły do

„Migration Policy Source” 2015, 15 VII, [online] http://www.migrationpolicy.org/article/euromai dan-protests-corruption-and-war-ukraine-migration-trends-and-ambitions, 25 IV 2016.

24 M. Kindler, M. Szulecka, The Economic Integration of Ukrainian and Vietnamese Migrant Women in a Polish Labour Market, "Journal of Ethnic and Migration Studies” 2013, Vol. 39, nr 1, s. 649-671, [online] http://dx.doi.org/10.1080/1369183X.2013.745244; M. Luptakova, Legal and Illegal Migration from Ukraine: An Analysis of Social and Security Issues, „International Journal of Criminal Justice Science” 2009, Vol. 4, nr 2, s. 144-159.

25 M. Jaroszewicz, M. Kindler, Irregular Migration from Ukraine and Belarus..., s. 18-19.

26 Y. Leontiyeva. B. Tollarová, Results from a Survey of Foreigners' Incomes, Expenditures and Remittances. Main Findings Concerning Remittances, „Sociologický ústav AV ČR” 2011; O. Kupets, The Development and the Side Effects of Remittances in the CIS countries: The Case of Ukraine, 2012, CARIM-East Research Report, 2. 
retoryki „sekurytyzacji” migracji, publicznego postrzegania jej w kontekście związków $\mathrm{z}$ terroryzmem międzynarodowym i islamskim fundamentalizmem. Nikos Papastergiadis podkreśla jednak, że od czasu rozpowszechnienia się migracji wraz z procesem modernizacji społecznej zawsze była ona postrzegana przez aparat państwowy jako wyzwanie i stawiano pytanie, co należy zrobić z migrantami, czy ich integrować, czy raczej trzymać $\mathrm{z}$ daleka ${ }^{27}$. $\mathrm{Z}$ punktu widzenia państwa przyjmującego najwięcej obaw budzi imigracja nieuregulowana, będąca przede wszystkim zjawiskiem prawnym i politycznym. Rozwój nieuregulowanej migracji to efekt strukturalnego niedopasowania politycznych i społecznych podstaw migracji, inaczej mówiąc - różnic między społecznymi i ekonomicznymi czynnikami przyciągającymi a politycznymi warunkami migracji. Efektywność narodowego lub ponadnarodowego sytemu kontroli przepływów migracyjnych jest bardzo ograniczona, a obecność innych systemów społecznych (zwłaszcza systemu ekonomicznego) współczesnego państwa zachęca do migracji, nawet jeśli polityka admisyjna ma na celu coś zupełnie odwrotnego. Polityka kontroli jest zatem raczej dążeniem do kontroli niż polityką możliwą do realnej implementacji.

Dlatego też, nawet jeśli z punktu widzenia rozważań teoretycznych porażką państwa narażającą go na ryzyka z zakresu bezpieczeństwa jest obecność nawet najmniejszej grupy migranckiej, o której istnieniu państwo nie wie i nad którą nie ma kontroli, to w praktyce porażką jest raczej obecność dużej grupy migrantów nieuregulowanych, podobnie jak wysokie prawdopodobieństwo, że taka grupa może przybyć. W przypadku migracji z Ukrainy do UE, choć zjawisko nieuregulowanej pracy (w mniejszym stopniu nieuprawnionego pobytu) niewątpliwie istnieje, to fakt, że państwa UE mają choć cząstkową wiedzę o tych osobach (dzięki temu, że przedostają się one legalnymi kanałami migracji), zmniejsza ewentualne prawdopodobieństwo porażki. Mimo wybuchu konfliktu zbrojnego na Ukrainie paradoksalnie ryzyka związane z migracją ukraińskich obywateli do UE wzrosły nieznacznie, także z tego względu, że Ukraińcy wykorzystują przede wszystkim legalne kanały migracji zarobkowej, nad którymi kraje UE mają pełną suwerenność i kontrolę.

Inaczej dzieje się w przypadku osób przedostających się do UE drogą śródziemnomorską, wykorzystujących możliwości płynące $\mathrm{z}$ prawa humanitarnego związane z ochroną międzynarodową. W tym przypadku państwo jest zobowiązane do przyjęcia tej kategorii cudzoziemców, nie może jednak nawet oszacować liczby, jaką musi przyjąć. Ponadto uchodźcy mają zwykle zagwarantowane prawo do pomocy socjalnej, podczas gdy migranci zarobkowi takiego prawa nie mają. W tej sytuacji najbardziej dotkliwym możliwym niepowodzeniem z punku widzenia krajów UE byłoby wznowienie walk we wschodniej Ukrainie, a także poważna destabilizacja całego kraju. Te czynniki mogłyby doprowadzić do sytuacji, w której to obywatele Ukrainy byliby zmuszeni do masowego opuszczenia kraju i ubiegania się o status uchodźcy w sąsiednich krajach, także w państwach UE.

Ryzyko związane z migracją z Ukrainy dla państw UE należy rozpatrywać na wielu płaszczyznach. Po pierwsze, aparat państwowy może być niechętny przyjmowaniu mi-

27 N. Papastergiadis, Wars of Mobility, „European Journal of Social Mobility” 2010, Vol. 13, nr 3, s. $343-$ 361, [online] http://dx.doi.org/10.1177/1368431010371756. 
grantów ze względów politycznych, w obawie przed negatywną reakcją społeczeństwa, jednak płaszczyzna ekonomiczna będzie przyciągała migrantów. Nie wchodząc w ekonomiczne rozważania, które nie są przedmiotem niniejszego artykułu, według wielu badań ukraińska migracja pozytywnie wpływa na gospodarki krajów przyjmujących, zaś ukraińscy migranci przyjmują pracę niechętnie podejmowaną przez lokalną ludność. Zawodowa dystrybucja obywateli Ukrainy na rynkach pracy jasno pokazuje, że są oni grupą komplementarną wobec miejscowej ludności ${ }^{28}$.

Ryzyka związane z migracją można także rozpatrywać w kategorii realizmu politycznego, a zatem rzeczywistych kosztów, jakie państwo ponosi, by zapobiec niekorzystnym zjawiskom związanych z migracją, oraz w kategorii konstruktywizmu, a zatem tego, w jakim kontekście polityczno-kulturowym funkcjonuje dane zjawisko. Jeśli chodzi o rzeczywiste koszty związane z migracją Ukraińców, to mówimy tu przede wszystkim o kosztach ich wydalenia i przetrzymywania w aresztach deportacyjnych w przypadku naruszenia prawa. Jest to jednak zjawisko incydentalne. Kolejne koszty dotyczą procedur związanych z procedurą przyznawania statusu uchodźcy obywatelom Ukrainy, jednak również w tym przypadku nie są to wysokie koszty zarówno w skali całej UE, jak i poszczególnych państw członkowskich.

Ponadto migracji często towarzyszą także takie niekorzystne zjawiska, jak przemyt migrantów i handel ludźmi. To pierwsze zjawisko jest przede wszystkim powiązane z migracją nieuregulowaną, a dokładniej z nielegalnym przekraczaniem granicy. Migranci, by zwiększyć swoje szanse dotarcia do planowanego kraju pobytu, często korzystają z pośrednictwa zorganizowanych grup przestępczych organizujących przerzut przez granicę. Dane Frontexu pokazują jednak, że obywatele Ukrainy rzadko decydują się na nielegalne przekroczenie granicy, a jeśli to robią, to raczej przekraczają granicę indywidualnie lub małych grupach, bez pośrednictwa przemytników ${ }^{29}$. Jeśli chodzi o ciężkie przestępstwo przeciwko wolności, życiu i zdrowiu człowieka, jakim jest handel ludźmi, to jest ono przede wszystkim skutkiem ubocznym migracji. Wynika głównie ze skłonności migrantów do podejmowania ryzyka bez dokładnych informacji na temat możliwych warunków czekających ich kraju docelowym. Zjawisko to było szczególnie natężone w latach 90. ubiegłego wieku, gdy obywatele Ukrainy nie dysponowali rozwiniętymi sieciami migracyjnymi w krajach UE oraz mieli bardzo ubogą wiedzę o możliwości legalnej migracji i obrony swoich praw jednostkowych. Według szacunków Międzynarodowej Organizacji Migracji z 2010 r. od roku 1991 około 100 tys. Ukraińców padło ofiarą handlu ludźmi ${ }^{30}$.

Jeśli chodzi o kontekst społeczno-polityczny, to jak już wcześniej wspomniano, nastroje społeczne w UE nie są generalnie przychylne migrantom, dochodzi do coraz częstszych wystąpień antymigranckich, choć są one głównie skierowane przeciw przy-

28 L. Barbone, Labour Migration from the Eastern Partnership Countries: Evolution and Policy Options for Better Outcomes, Warsaw 2013, CASE Network Reports, 0113; P. Kaczmarczyk, Burden or Relief? Fiscal Impacts of Recent Ukrainian Migration to Poland, 2015, IZA Discussion Paper, nr 8779.

Frontex, Eastern European Borders Risk Assessment 2014.

30 International Organisation for Migration, Combating trafficking in Human Beings: Ukraine 2010. 
byszom z krajów muzułmańskich. Według sondażu CBOS badającego stosunek Polaków do przedstawicieli innych narodowości ze stycznia 2015 r. 36\% Polaków deklaruje sympatię dla tej grupy, lecz jednocześnie aż 30\% deklaruje niechęćs' ${ }^{11}$ Jako przykład kraju, w którym rozwinął się protest społeczny przeciwko napływowi obywateli Ukrainy, można pokazać Portugalię, do której w latach 1999-2002 napłynęło około 200 tys. ukraińskich migrantów. Co ciekawe jednak, w protestach tych uczestniczyli przede wszystkim tzw. „tradycyjni” migranci, a zatem osoby przybyłe z byłych kolonii portugalskich $^{32}$. Także w Czechach wraz z nastaniem tam recesji gospodarczej społeczeństwo zaczęło jednoznacznie wyrażać poglądy niechętne obecności obywateli Ukrainy ${ }^{33}$.

\section{PERSPEKTYWA KRAJU WYSYŁAJĄCEGO}

W zależności od stopnia rozwoju społeczno-gospodarczego danego kraju i jego sytuacji demograficznej emigracja własnych obywateli może być szansą lub zagrożeniem. Szansą jest wówczas, gdy dane państwo nie jest w stanie zapewnić pracy i godnych warunków życia swoim obywatelom, a brak możliwości wyjazdu sprzyja radykalizacji społecznej, wzrostowi przestępczości i innym negatywnym zjawiskom społecznym. Jednak o ile emigracja może odciążyć władze państwowe od często niemożliwej z różnych przyczyn poprawy sytuacji na rynku pracy czy zwiększenia efektywności systemu opieki społecznej, o tyle niewątpliwie uszczupla zasoby demograficzne danego kraju. Taka sytuacja ma miejsce na Ukrainie. Nawet jeśli migracja Ukraińców jest efektywnym sposobem tego społeczeństwa na radzenie sobie z biedą i rozładowuje napięcia społeczne ${ }^{34}$, to porażką tego kraju związaną z migracją jest przede wszystkim pogarszająca się sytuacja demograficzna, w tym spadek liczby ludności, zwłaszcza tej w wieku produkcyjnym. W latach 1992-2004 na stałe z Ukrainy wyjechało 25 mln obywateli Ukrainy ${ }^{35}$. Jeśli chodzi o późniejsze wyjazdy, to istnieją problemy metodologiczne z ich oceną. Można jednak szacować, że do poprzedniej grupy emigrantów dołączyła grupa około 200 tys. osób, które wyjechały z Ukrainy po 2004 r. i otrzymały obywatelstwa innych państw. Trudno szacować, na ile trwała jest obecna migracja z Ukrainy i ile z obecnych 800 tys. osób posiadających prawo pobytu w UE zamierza tam pozostać na zawsze. Ponadmilionowa diaspora przebywa także w Rosji. Nadal w zdecydowanej większości przypadków

31 Sondaż: Polacy najbardziej nie lubia Romów i Rosjan. Ukraińcy budzq największe emocje, PAP, 30 I 2015.

32 V. Susak, Ukrainian Guest Workers and Immigrants in Portugal (1997-2002), „Ukrainians in the Contemporary World: conference of the Ukrainian graduates of American educational programmes", Kyiv 2002.

33 D. Drbohlav i in., The Czech Republic: on its Way from Emigration to Immigration Country, 2009, IDEA Working Papers, nr 11.

$34 \quad$ O. Betliy, The Perspective...

35 M. Jaroszewicz. L. Szerepka, Wyzwania migracyjne w państwach wschodniego sąsiedztwa Unii Europejskiej, Warszawa 2007, s. 87-88. 
jest to migracja krótkoterminowa, lecz po wybuchu konfliktu zbrojnego widać pewną tendencję do zmiany tej formy migracji w migrację osiedleńczą ${ }^{36}$.

Kolejnym ryzykiem dla Ukrainy związanym z migracją jej obywateli jest problem zajmowania przez nich przede wszystkim niższych segmentów rynku pracy w krajach przyjmujących, często w nieformalnym sektorze zatrudnienia. Oznacza to, że migranci albo nie podlegają ubezpieczeniu emerytalnemu i zdrowotnemu, albo też odprowadzone składki nie trafiają na Ukrainę. W tej sytuacji to państwo ukraińskie będzie musiało ponieść koszty wypłacenia tym migrantom emerytur, gdy powrócą oni do kraju. Ukraina powinna ponieść także koszty reintegracji swoich obywateli, w tym pomóc im odnaleźć się na rynku pracy. Szczególnie niekorzystnym zjawiskiem społecznym dla Ukrainy jest dość masowa migracja edukacyjna wynikająca z niskiej jakości nauczania i korupcji występujących na ukraińskich uczelniach. Negatywną konsekwencją migracji jest również występowanie tzw. eurosierot, czyli dzieci pozostawionych przez migrantów pod opieką krewnych ${ }^{37}$.

Zasadniczym problemem państwa ukraińskiego jest brak aktywnej i przemyślanej polityki emigracyjnej, a zatem polityki skierowanej do diaspory za granicą, pozwalającej na utrzymanie kontaktu z migrantami i jednoczesne wykorzystanie zgromadzonego przez nich kapitału społecznego do dalszego rozwoju kraju. Ukraińskie władze państwowe pozostają stosunkowo pasywne, jeśli chodzi o politykę emigracyjną - jej motorami pozostają Kościół greckokatolicki, środowiska pozarządowe i organizacje diaspory. Organizacje tzw. starej diaspory, a zatem emigracji ukraińskiej przełomu XIX i XX w., są na tyle potężne, że mogłyby podjąć się mediacji na rzecz nowej fali migracji w krajach przyjmujących, ułatwić ich integrację. Dotychczasowe badania wskazują jednak, że kolejne pokolenia migrantów w niewielkim stopniu się ze sobą komunikują, a doświadczenia i zachowania nowych migrantów (zwłaszcza te wynikające z radzieckiej spuścizny) są zbyt odlegle dla tych z tradycyjnych środowisk ukraińskich ${ }^{38}$.

Także presja Unii Europejskiej w ramach dialogu mającego doprowadzić do zniesienia wiz dla obywateli Ukrainy podróżujących do strefy Schengen zmusza władze ukraińskie do aktywniejszego zajęcia się kwestią emigracji za granicą ${ }^{39}$. Jednocześnie ukraińscy migranci zarobkowi nie są przedstawiani w pozytywnym świetle w ukraińskim dyskursie publicznym oraz w mediach. Są oni raczej prezentowani jako pasywne ofiary okoliczności ekonomicznych, nieuczciwych pracodawców i pośredników, a nie jako osoby przedsiębiorcze, starające się jak najlepiej zarządzać podejmowanym przez siebie ryzkiem ${ }^{40}$.

36 M. Jaroszewicz, Kryzysowa migracja...

37 O. Kupets, The Development...

38 N. Khanenko-Friesen, Ukrainian Otherlands. Diaspora, Homeland, and Folk Imagination in the Twentieth Century, Madison 2015, Folklore Studies in a Multicultural World.

39 Szerzej zob.: M. Jaroszewicz, P. Kaźmierkiewicz, Does Ukraine Have a Policy on Emigration? Transcending the State-Centered Approach, "Central and Eastern European Migration Review” 2014, Vol. 3, nr 1, s. 11-26.

40 V. Volodko, Transnational Family Practices of Ukrainian Female Labour Migrants in Poland, [w:] Selling One's Favourite Piano to Emigrate. Mobility Patterns in Central Europe at the Beginning of the 21st Century, red. J. Isański, P. Luczys, Newcastle upon Tyne 2011. 
Z drugiej strony należy pamiętać, że po aneksji Krymu i faktycznej utracie części Donbasu Ukraina przeżyła poważne załamanie gospodarcze. PKB Ukrainy spadło o $7 \%$ w 2014 r. i o kolejne $16 \%$ w 2015 r. PKB per capita mierzone według parytetu siły nabywczej wyniosło w $2014 \mathrm{r}$. mniej niż 1000 dolarów - była to jedna trzecia dochodu krajowego na osobę odnotowywanego w $2010 \mathrm{r}$. W tej sytuacji warto zwrócić uwagę na pozytywną rolę emigracji, rozumianej przez Marka Okólskiego jako proces „rozgęszczania” pozwalający na uniknięcie konfliktów społecznych oraz łagodzący skutki niezdolności ukraińskiego rynku pracy do wchłonięcia nadwyżek ${ }^{41}$. Warto jednak pamiętać, że ze względu na długotrwałą nieumiejętność państwa ukraińskiego przeprowadzenia reform instytucjonalnych pozwalających na wchłoniecie nadwyżek ludności na rynku pracy nie należy raczej oczekiwać, że obecna fala emigracji spełni swoją funkcję modernizacyjną $\mathrm{w}$ tym sensie, że doprowadzi do rozprzestrzenienia się procesow modernizacyjnych na całym terytorium Ukrainy i zmniejszy atrakcyjność dalszych migracji. Współczesna emigracja z Ukrainy ma raczej formę opuszczenia państwa, które nie gwarantuje swoim obywatelom deklarowanych praw i możliwości rozwoju.

\section{KONKLUZJE}

Analiza migracji z perspektywy ryzyka wydaje się adekwatnym i pojemnym podejściem badawczym do politologicznego badania migracji, zwłaszcza w przypadku migracji nieuregulowanej. Badanie zjawisk społecznych z perspektywy ryzyka pozwala dogłębniej poznać procesy zmienne $\mathrm{w}$ czasie, $\mathrm{w}$ których przypadku istnieje wysokie prawdopodobieństwo przyszłego niepowodzenia i do analizy których brakuje dokładnych danych ilościowych. Takim zjawiskiem są niewątpliwie migracje międzynarodowe. Zastosowanie perspektywy ryzyka pozwala także wprowadzić do badania migracji niezwykle istotny kontekst społeczno-polityczny, uchwycić znaczenie czynników subiektywnych, takich jak percepcja przy podejmowaniu decyzji migracyjnych w przypadku migranta i planowanie określonej polityki migracyjnej w przypadku państwa.

Przede wszystkim jednak zastosowanie teorii ryzyka pozwala na systemowe porównanie perspektywy migranta oraz perspektywy państw docelowych i państwa pochodzenia. Zderzenie tych perspektyw umożliwia zweryfikowanie metod planowania i efektywności polityk migracyjnych prowadzonych przez państwa poprzez pokazanie, w jaki sposób migranci planują migrację, jak dokonują analizy ryzyka i jak starają się ominąć przeszkody narzucane im przez państwową politykę kontroli migracji.

Wydaje się, że takie dwuwymiarowe badanie migracji z perspektywy ryzyka ponoszonego przez migranta (jednostkę ludzką) z jednej strony i przez państwo wraz $z$ rozbudowanym aparatem kontroli i przymusu oraz skomplikowanym procesem decyzyjnym z drugiej może być zakwalifikowane jako próba poszerzenia dorobku tzw. krytycznych studiów nad migracjami. Krytyczne badania nad migracjami to nowe multidyscyplinarne podejście starające się odejść od utrwalonych metod badań nad

41 M. Okólski, Modernizacyjna rola migracji, Warszawa 2011, CMR Working Papers, nr 46 (104). 
migracjami przez większe włączenie perspektyw z zakresu prawa międzynarodowego, stosunków międzynarodowych, bezpieczeństwa i badań nad migracją przymusową, geografii i innych, a przede wszystkim skonfrontowanie badań makro z indywidualną perspektywą migranta.

Zastosowanie perspektyw ryzyka do badania migracji obywateli Ukrainy do Unii Europejskiej, w szczególności po wybuchu wojny w Donbasie i aneksji Krymu, pokazało, że mimo zwiększenia się ogólnej dynamiki migracji z Ukrainy potencjalne negatywne skutki tych migracji dla samych migrantów oraz dla państw przyjmujących zwiększyły się w niewielkim stopniu. Jeśli chodzi o migrantów, takie czynniki, jak fakt, że obywatele Ukrainy w większości przebywają w UE legalnie, a także starają się zalegalizować zatrudnienie, pozwalają im minimalizować ryzyka związane z ewentualnym zatrzymaniem czy wydaleniem, a także ominąć grupy przestępcze trudniące się zorganizowanym przemytem ludzi. Niewątpliwie znaczący spadek dochodów per capita odnotowany w związku z wybuchem wojny na Ukrainie i dalsza pauperyzacja społeczeństwa stwarza ryzyko, że migranci będą coraz bardziej gotowi przyjmować bardziej ryzykowne propozycje zatrudnienia, zaś utrata pracy staje się dla nich o wiele bardziej dotkliwa. Ponadto wzrost nastrojów antymigranckich w UE i zaostrzająca się polityka migracyjna związana z kryzysem uchodźczym także może negatywnie odbić się zarówno na dalszym prawnym statusie ukraińskich migrantów, jak i na ich integracji w społeczeństwach przyjmujących.

Jeśli chodzi o kraje przyjmujące migrantów, to w zasadzie jedynie Polska odnotowała w ostatnich dwóch latach zwiększony napływ obywateli Ukrainy. Stworzyło to co prawda pewne nowe ryzyka, jednak głównie związane z kwestiami efektywnego zarządzania tym napływem. Jeśli wziąć pod uwagę fakt, że większość ukraińskich migrantów przybywa do Polski w ramach kanałów ułatwionej pracy krótkoterminowej, oznacza to, że polski rynek pracy nadal ma możliwości absorpcji tych pracowników. Warto zastanowić się, jakie, w świetle teorii ryzyka, argumenty przemawiają za wyborem Polski przez migrantów ukraińskich. Niewątpliwie dotychczasowe doświadczenia migracyjne setek tysięcy Ukraińców, liberalna polityka wizowa i migracyjna, rozbudowane sieci migracyjne zmniejszają ryzyko niepowodzenia samego procesu migracji, nawet jeśli jego skutkiem są zdecydowanie niższe płace niż te zwykle osiągane przez migrantów w krajach Europy Zachodniej. W tym kontekście warto byłoby podjąć dalszą analizę i zastanowić się, czy wraz z oswojeniem ryzyka migracyjnego przez obywateli Ukrainy i wzrostem gotowości podjęcia dalszych wyzwań Polska może przestać być atrakcyjnym krajem docelowym.

Największym ryzykiem mogącym skutkować poważnymi konsekwencjami politycznymi, gospodarczymi i społecznymi dla UE byłaby poważna destabilizacja, w tym ewentualność wybuchu konfliktu zbrojnego na terytorium całej Ukrainy, mogące skutkować niekontrolowanym napływem uchodźców wymagających kosztowych programów pomocy socjalnej.

Ukraina wydaje się ponosić największe długoterminowe ryzyka związane ze zwiększoną migracją swoich obywateli. Nawet jeśli w krótkiej perspektywie migracja obywateli pozwala na złagodzenie skutków kryzysu gospodarczego oraz napięć na rynku 
pracy i wsparcie gospodarki transferami pieniężnymi od migrantów, to w długiej perspektywie kraj traci dużą rzeszę osób w młodym i średnim wieku. Tymczasem Ukraina w ciągu ostatnich dwudziestu lat faktycznie straciła około $20 \%$ swojej populacji. W niewielkim stopniu udało się jej także poprawić dynamikę dzietności oraz zmniejszyć śmiertelność, co czyni ją jednym z globalnych „liderów” niekorzystnych przemian demograficznych. W tym kontekście warto byłoby zbadać ewentualny potencjał powrotowy Ukraińców, a także zastanowić się, jaką docelową politykę emigracyjną powinna prowadzić Ukraina, by stymulować ewentualne powroty lub przynajmniej dopuścić diasporę do bardziej aktywnego udziału w rozwoju ukraińskiego państwa.

Ponieważ niniejszy tekst ma niejako charakter prekursorski, kilka podjętych w nim pytań badawczych wymaga dalszych badań. W szczególności dalsze badanie perspektywy migranta powinno skupić się na zastanowieniu, jak odmiennie ryzyko jest postrzegane w zależności od tego, czy uznajemy, że decyzja migracyjna była podjęta indywidualnie, czy też jako wspólna decyzja gospodarstwa domowego. Jak wynika z analizy dotychczasowej literatury na temat migracji Ukraińców do UE, decyzja migracyjna jest zwykle poodejmowana kolektywnie, co pozwala na zminimalizowanie ryzyka dla rodzin, jednak teza ta wymaga dogłębnego zbadania. Drugą ważną kwestią jest konieczność kompleksowego przeanalizowania przyczyn, dla których ukraińscy migranci (także ci pochodzący z terenów bezpośrednio poszkodowanych przez konflikt zbrojny na wschodzie Ukrainy) tak rzadko decydują się na złożenia wniosku o status uchodźcy na terenie UE. Wydaje się, że jest to świadomie wybrana strategia kalkulacji ryzyka, niechęć do podejmowania zbyt wysokiego ryzyka, nawet jeśli ostateczny rezultat byłby bardziej korzystny (długoterminowe prawo pobytu plus ewentualna pomoc socjalna) niż w przypadku, gdy wykorzystywane są kanały migracji zarobkowej.

\section{BIBLIOGRAFIA}

Arunraj N.S., Mandal S., Maiti J., Modeling Uncertainty in Risk Assessment: An Integrated Approach with Fuzzy Set Theory and Monte Carlo Simulation, „Accident Analysis and Prevention” 2013, Vol. 55, nr 3, [online] http://dx.doi.org/10.1016/j.aap.2013.03.007.

Banulescu-Bogdan N., Fratzke S., Europe's Migration Crisis in Context: Why Now and What Next?, „Migration Policy Source” 2015, 24 IX, [online] http://www.migrationpolicy.org/ article/europe-migration-crisis-context-why-now-and-what-next.

Barbone L., Labour Migration from the Eastern Partnership Countries: Evolution and Policy Options for Better Outcomes, Warsaw 2013, CASE Network Reports, 0113.

Betliy O., The Perspective of Ukraine, [w:] Forecasting Migration between the EU, V4 and Eastern Europe. Impact of Visa Abolition, red. M. Jaroszewicz, M. Lesińska, Warsaw 2014, Raport OSW.

Drbohlav D. i in., The Czech Republic: on its Way from Emigration to Immigration Country, 2009, IDEA Working Papers, nr 11.

Drbohlav D., Jaroszewicz M., The Probable Future Development in International Migration from Ukraine, Belarus and Moldova to Visegrad Countires and the EU, [w:] Forecasting Migra- 
tion between the EU, V4 and Eastern Europe. Impact of Visa Abolition, red. M. Jaroszewicz, M. Lesińska, Warsaw 2014, Raport OSW.

Düvell F., Lapschyna I., The EuroMaidan Protests, Corruption, and War in Ukraine: Migration Trends and Ambitions, „Migration Policy Source” 2015, 15 VII, [online] http://www.mi grationpolicy.org/article/euromaidan-protests-corruption-and-war-ukraine-migrationtrends-and-ambitions.

Eurostat News Release, 185/2015,20X2015, [online] http://ec.europa.eu/eurostat/documents/ 2995521/7038745/3-20102015-BP-EN.pdf/70063124-c3f2-4dfa-96d5-aa5044b927a6.

Faist T., „Extention do domaine de la lutte”: International Migration and Security before and after September 11, „International Migration Review” 2002, Vol. 31, nr 1, [online] http://dx.doi. org/10.1111/j.1747-7379.2002.tb00065.x.

Forecasting Migration between the EU, V4 and Eastern Europe. Impact of Visa Abolition, red.

M. Jaroszewicz, M. Lesińska, Warsaw 2014, Raport OSW.

Frontex, Eastern European Borders Risk Assessment 2014.

Huysmans J., The Politics of Insecurity. Fear, Migration and Asylum in the EU, London-New York 2006, New International Relations.

International Organisation for Migration, Combating trafficking in Human Beings: Ukraine 2010.

Jaroszewicz M., Kryzysowa migracja Ukrainców, „Komentarze OSW” 2015, 19 X.

Jaroszewicz M., Polska bardziej atrakcyjna dla ukrainskich imigrantów zarobkowych, „Analizy OSW” 2013, 12 VI.

Jaroszewicz M., Kaźmierkiewicz P., Does Ukraine Have a Policy on Emigration? Transcending the State-Centered Approach, „Central and Eastern European Migration Review” 2014, Vol. 3, nr 1.

Jaroszewicz M., Kindler M., Irregular Migration from Ukraine and Belarus to the EU. A Risk Analysis Study, Warsaw 2015, CMR Working Papers, nr 80 (138).

Jaroszewicz M., Szerepka L., Wyzwania migracyjne w państwach wschodniego sąsiedztwa Unii Europejskiej, Warszawa 2007.

Kaczmarczyk P. Burden or Relief? Fiscal Impacts of Recent Ukrainian Migration to Poland, 2015, IZA Discussion Paper, nr 8779.

Khanenko-Friesen N., Ukrainian Otherlands. Diaspora, Homeland, and Folk Imagination in the Twentieth Century, Madison 2015, Folklore Studies in a Multicultural World.

Kindler M., A Risky Business? Ukrainian Migrant Women in Warsaw's Domestic Work Sector, Amsterdam 2011, IMISCOE Dissertations.

Kindler M., Szulecka M., The Economic Integration of Ukrainian and Vietnamese Migrant Women in a Polish Labour Market, „Journal of Ethnic and Migration Studies” 2013, Vol. 39, nr 1, [online] http://dx.doi.org/10.1080/1369183X.2013.745244.

Kupets O., The Development and the Side Effects of Remittances in the CIS countries: The Case of Ukraine, 2012, CARIM-East Research Report, 2.

Leontiyeva Y., Tollarová B., Results from a Survey of Foreigners' Incomes, Expenditures and Remittances. Main Findings Concerning Remittances, „Sociologický ústav AV ČR” 2011.

Luptakova M., Legal and Illegal Migration from Ukraine: An Analysis of Social and Security Issues, „International Journal of Criminal Justice Science” 2009, Vol. 4, nr 2. 
Massey D.S. i in., Theories of International Migration: A Review and Appraisal, „Population and Development Review” 1993, Vol. 19, nr 3, [online] http://dx.doi.org/10.2307/2938462. Niemann A., Schmidthäussler N., The Logic of EU Policy Making on (Irregular) Migration: Securitisation or Risk?, Paper given at the UACES conference: „Exchanging Ideas on Europe 2012: Old Borders - New Frontiers”, 3-5 IX 2012, Passau, Germany.

Okólski M., Modernizacyjna rola migracji, Warszawa 2011, CMR Working Papers, nr 46 (104). Papastergiadis N., Wars of Mobility, „European Journal of Social Mobility” 2010, Vol. 13, nr 3, [online] http://dx.doi.org/10.1177/1368431010371756.

Renn O., Concepts of Risks: A Classification, [w:] Social Theories of Risk, red. S. Krimsky, D. Golding, Westport 1992.

Sondaz: Polacy najbardziej nie lubią Romów i Rosjan. Ukraińcy budzq największe emocje, PAP, 30 I 2015.

Stark O., The Migration of Labour, Cambridge-Oxford 1991.

Stark O., Bloom D.E., The New Economics of Labour Migration, „American Economic Review” 1985, Vol. 74, nr 2.

Susak V., Ukrainian Guest Workers and Immigrants in Portugal (1997-2002), „Ukrainians in the Contemporary World: conference of the Ukrainian graduates of American educational programmes", Kyiv 2002.

Valverde M., Police, Sovereignty and Law: Faoucaultian Reflections, [w:] Police and the liberal state, red. M.D. Dubber, M. Valverde, Standford 2008, Critical Perspectives on Crime and Law. Volodko V., Transnational Family Practices of Ukrainian Female Labour Migrants in Poland, [w:] Selling One's Favourite Piano to Emigrate. Mobility Patterns in Central Europe at the Beginning of the 21st Century, red. J. Isański, P. Luczys, Newcastle upon Tyne 2011.

Zinn J.O., Taylor-Gooby P., The Current Significance of Risk, [w:] Risk in Social Science, red. ciż, Oxford 2006.

Dr Marta JAROSZEWICZ jest głównym specjalistą, koordynatorem projektu migracyjnego w Ośrodku Studiów Wschodnich (OSW) w Warszawie. Z wykształcenia politolog, ma doktorat z zakresu bezpieczeństwa międzynarodowego. Jej główne zainteresowania badawcze dotyczą procesów i polityk migracyjnych krajów Europy Wschodniej, a także zastosowania metod politologicznych do badania migracji, w tym w szczególności teorii z zakresu analizy ryzyka i bezpieczeństwa. 